\title{
Gene Expression Profiling of Hypothalamic Hamartomas: A Search for Genes Associated with Central Precocious Puberty
}

\author{
Anne-Simone Parent ${ }^{\mathrm{a}}$ Valerie Matagne ${ }^{\mathrm{a}}$ Manfred Westphal ${ }^{\mathrm{b}}$ Sabine Heger ${ }^{\mathrm{a}}$ \\ Sergio Ojeda ${ }^{\text {a Heike Jung }}{ }^{\text {a }}$ \\ ${ }^{a}$ Division of Neuroscience, Oregon National Primate Research Center, Beaverton, Oreg., USA; \\ ${ }^{b}$ Clinics of Neurosurgery, University Hospital Hamburg-Eppendorf, Hamburg, Germany
}

\section{Key Words}

Hypothalamic hamartoma - Gene expression - Precocious

puberty $\cdot$ DNA arrays $\cdot$ Seizures

\begin{abstract}
Background: Hypothalamic hamartomas (HHs) are congenital lesions composed of neurons and astroglia. Frequently, $\mathrm{HHs}$ cause central precocious puberty (CPP) and/or gelastic seizures. Because HHs might express genes similar to those required for the initiation of normal puberty, we used cDNA arrays to compare the gene expression profile of an $\mathrm{HH}$ associated with CPP with three HHs not accompanied by sexual precocity. Methods: Global changes in gene expression were detected using Affymetrix arrays. The results were confirmed by semiquantitative PCR, which also served to examine the expression of selected genes in the hypothalamus of female monkeys undergoing puberty. Results: All HHs were associated with seizures. Ten genes whose expression was increased in the HH with CPP were identified. They encode proteins involved in three key cellular processes: transcriptional regulation, cell-cell signaling, and cell adhesiveness. They include $I A-1$ and MEF2A, two transcription factors required for neuronal development; $m G$ GluR1 and VILIP-1, which encode proteins involved in neuronal communication, and
\end{abstract}

\section{A.S. Parent and V. Matagne contributed equally to this work.}

\section{KARGER}

Fax +41613061234

E-Mail karger@karger.ch

www.karger.com
(C) 2007 S. Karger AG, Base

0301-0163/08/0692-0114\$24.50/0

Accessible online at:

www.karger.com/hre
TSG-6 that encodes a protein involved in cell adhesiveness. Of these, expression of $m G / u R 1$ also increases in the female monkey hypothalamus at puberty. Conclusions: Increased expression of these genes in $\mathrm{HH}$ s may be relevant to the ability of some HHs to induce sexual precocity.

Copyright $\odot 2007$ S. Karger AG, Basel

\section{Introduction}

Puberty results from the activation of a complex neuroendocrine machinery set in motion by a primary mechanism yet to be identified. Once under way, this activational process results in the diurnally timed resurgence of pulsatile gonadotropin hormone-releasing hormone $(\mathrm{GnRH})$ secretion, which in turn stimulates the secretion of luteinizing hormone and follicle-stimulating hormone from the pituitary gland.

It appears now well-established that GnRH secretion during sexual development is mainly controlled by neuronal networks utilizing excitatory and inhibitory amino acids for neurotransmission. It is also believed that the pubertal activation of GnRH release depends on a coordinated increase in glutamatergic stimulation of $\mathrm{GnRH}$ neurons and a decrease in $\gamma$-aminobutyric acid inhibition [reviewed in 1]. In addition to these 'classical' neurotransmitters, the peptide metastatin/kisspeptin produced by discrete hypothalamic neuronal subsets [2] has

Tel. +1 503690 5303, Fax +1 503690 5384,E-Mail ojedas@ohsu.edu 
Table 1. HHs used in this study and associated clinical characteristics

\begin{tabular}{lllllll}
\hline Patient & Age at surgery & Precocious puberty & Gender $\begin{array}{l}\text { Age at onset } \\
\text { of puberty }\end{array}$ & $\begin{array}{l}\text { GnRH } \\
\text { treatment }\end{array}$ & Seizures \\
\hline 1 & 7 years, 8 months & Yes & M & $3-4$ years & Yes & Yes \\
2 & 9 years & No & M & - & - & Yes \\
3 & 5 years, 2 months & 3 months after surgery & F & 5 years, 3 months & Yes \\
4 & 37 years & No & M & - & - & Yes \\
5 & 14 years & Yes & F & 5 years & Yes $^{1}$ & Yes \\
\hline
\end{tabular}

${ }^{1}$ Discontinued before surgery.

been recently identified as playing a pivotal role in the initiation of puberty $[3,4]$. GnRH neuronal activity is not only controlled by these transsynaptic inputs, but also by glial cells that facilitate $\mathrm{GnRH}$ secretion via the activation of signaling pathways initiated by growth factors acting on receptors endowed with tyrosine- and serine-threonine kinase activity [reviewed in 1].

The search for those precipitating events responsible for the initiation of puberty may benefit not only from studying the normal process of puberty in animal models and humans, but also from the analysis of pathological conditions affecting pubertal development in humans. Hypothalamic hamartomas ( $\mathrm{HHs}$ ) represent one of these conditions. They are congenital nonneoplastic lesions containing mature brain tissue in a heterotopic location, commonly associated with the base of the hypothalamus [5]. In most cases, HHs contain neurons and astroglial cells of normal aspect in addition to astrocytes and ependymoglial-like cells [6]. If $\mathrm{HH}$ are symptomatic, they are frequently associated with central precocious puberty (CPP) and/or gelastic seizures, a form of ictal laughter [7].

In both sexes, sexual precocity caused by $\mathrm{HH}$ occurs much earlier (1-2 years of age) than idiopathic precocious puberty, which predominantly affects females. The mechanism by which they advance puberty so dramatically is still unknown. Because HHs appear to contain all the necessary components to initiate the pubertal process at a very early age, they might hold critical information concerning the transcriptional and/or signaling components underlying sexual precocity and the initiation of normal puberty in humans. In this study, we used cDNA microarrays to compare the gene expression profiles of an $\mathrm{HH}$ associated with CPP to that of HHs not accompanied by precocious puberty with the aim of identifying genes whose expression may be selectively altered in the $\mathrm{HH}$ with CPP. The results showed the genes most highly over- expressed in the $\mathrm{HH}$ associated with $\mathrm{CPP}$ were genes encoding transcriptional regulators required for neuronal differentiation and survival, and genes encoding proteins required for excitatory cell-cell communication.

\section{Patients and Methods}

\section{Patients}

HHs from 4 patients were used for DNA array analysis and semiquantitative PCR. In addition, the expression of selected genes from a fifth $\mathrm{HH}$ was analyzed by semiquantitative PCR only. In all cases, the HHs were surgically resected due to intractable seizure activity. With the exception of patient 3 and 5 , all other patients were males. Only patients 1 and 5 exhibited CPP before surgery (table 1). However, the evolution of these two cases was different, because the $\mathrm{HH}$ of patient 5 was removed at 14 years of age ( 9 years after CPP was diagnosed), during the course of normal puberty and 1 year after discontinuation of treatment with a GnRH agonist. The $\mathrm{HH}$ of patient 1 was resected much sooner (at approximately 8 years of age), 4 years after the manifestation of CPP, and while the patient was still being treated with a GnRH agonist. The 3 other patients had seizures, but not CPP at the time of $\mathrm{HH}$ resection. Patient 3 (female) exhibited CPP 3 months after surgery (table 1). A fragment of each $\mathrm{HH}$ was routinely processed for histopathological examination, and tissue samples not needed for diagnostic purposes were stored at $-80^{\circ} \mathrm{C}$ for future reference or research.

These preexisting samples were sent to Beaverton, Oreg., USA as unlinked, anonymous specimens for RNA processing. The experimental protocol for this project was approved by the Institutional Review Board for Human Subjects of the Oregon Health \& Science University.

\section{Nonhuman Primates}

The hypothalamic tissue used in this study derived from early juvenile (8.9-11.7 months of age, $n=5)$, late juvenile (1.2-1.8 years of age, $n=4)$, early pubertal ( $2-3$ years of age, $n=4)$ and mid-pubertal (3-4 years of age, $\mathrm{n}=6$ ) female monkeys (Macaca mulatta) that had been euthanized for a variety of reasons and obtained through the Oregon National Primate Research Center (ONPRC) Necropsy Program. The developmental stages of the animals were defined according to the criteria proposed by Watanabe and 
Table 2. Genes showing a 2 -fold increase or more in an $\mathrm{HH}$ associated with precocious puberty (HH-1) in comparison to HHs not accompanied by sexual precocity (HH-2 to 4 )

\begin{tabular}{|c|c|c|c|c|c|}
\hline $\begin{array}{l}\text { Accession } \\
\text { No. }\end{array}$ & Gene identity & $\begin{array}{l}1 \text { - vs. } 2 \text {-fold } \\
\text { increase }\end{array}$ & $\begin{array}{l}1 \text { - vs. } 3 \text {-fold } \\
\text { increase }\end{array}$ & $\begin{array}{l}1 \text { - vs. } 4 \text {-fold } \\
\text { increase }\end{array}$ & $\begin{array}{l}\text { Mean fold } \\
\text { increase }\end{array}$ \\
\hline U30872.1 & Centromere protein $\mathrm{F}$ (mitosin) & 4.29 & 3.25 & 6.5 & 4.68 \\
\hline NM_002196.1 & Insulinoma-associated 1 (IA1) & 4.29 & 2.3 & 10.56 & 5.72 \\
\hline NM_005587.1 & MEF2A transcription enhancer factor 2 & 3.48 & 2 & 2.83 & 2.77 \\
\hline NM_000838.2 & Glutamate receptor metabotropic $1 \alpha$ (mGluR1A) & 3.48 & 2.14 & 3.73 & 3.13 \\
\hline NM_003385.1 & Visinin-like 1 (VILIP-1) & 3.73 & 2.3 & 4.59 & 3.54 \\
\hline $\mathrm{AI} 0 \overline{4} 0163$ & Calcium channel, voltage-dependent, $\beta_{2}$-subunit & 3.73 & 2 & 3.03 & 2.92 \\
\hline AF047033.1 & $\begin{array}{l}\text { Solute carrier family 4, sodium bicarbonate cotransporter, } \\
\text { member } 7 \text { (SLC4A7) }\end{array}$ & 2.64 & 2.14 & 2.64 & 2.47 \\
\hline AJ300461.1 & Transmembrane protein 16C (C11ORF25) & 5.28 & 4 & 6.5 & 5.26 \\
\hline R41498 & $\mathrm{T}$ cell activation leucine repeat-rich protein & 3.25 & 2.83 & 3.25 & 3.11 \\
\hline NM_007115 & Tumor necrosis factor alpha-stimulated gene 6 (TSG-6) & 3.73 & 2.3 & 3.73 & 3.25 \\
\hline
\end{tabular}

Terasawa [8]. All procedures were approved by the ONPRC Animal Care and Use Committee in accordance with the NIH guidelines for the use of animals in research.

\section{RNA Extraction}

Total RNA from the $\mathrm{HH}$ samples and the nonhuman primate brain was extracted as outlined in online supplementary note 1 (www.karger.com/doi/10.1159/000111815). RNA from the human placenta and human fetal brain was purchased from BD Biosciences (San Jose, Calif., USA); total RNA from human hypothalami was obtained from Ambion (Austin, Tex., USA).

\section{Sample Preparation and Microarray Hybridization}

Microarray assays were performed by the Affymetrix Microarray Core of the OHSU Gene Microarray Shared Resource, as described in online supplementary note 2 (www.karger.com/ doi/10.1159/000111815).

\section{Microarray Data Analysis}

Image processing and expression analysis were carried out using Affymetrix Microarray Suite (MAS) 5.0 software, as described in online supplementary note 3 (www.karger.com/doi/10.1159/ 000111815). The array data have been deposited in NCBIs Gene Expression Omnibus (GEO, http://www.ncbi.nlm.nih.gov/geo/; accession number GSE7142).

\section{Semiquantitative PCR Validation of Array Results}

Five genes showing an increased expression of 2 -fold or greater in the $\mathrm{HH}$ associated with CPP (patient 1 , male) versus the $\mathrm{HH}$ from the 2 male patients without CPP (patients 2 and 4), and the $\mathrm{HH}$ from a female patient showing puberty after surgery $(\mathrm{HH}-3)$ were selected for PCR verification of the array results. The same genes were also examined in an additional $\mathrm{HH}$ (patient 5) not subjected to array analysis. The five genes studied were $I A-1$, VILIP-1, TSG-6, mGluR1A, and MEF2A (table 2). Reverse transcription of total RNA (50 ng) from each sample and PCR amplification was performed as outlined in online supplementary note 4 (www.karger.com/doi/10.1159/000111815). Other genes exam- ined were GnRH, TGF $\alpha$, KiSS1, and GPR54 using primers and PCR conditions described in online supplementary note 4 . Densitometric analysis of the gels was performed using Quantity One software (Bio-Rad, Hercules, Calif., USA). The results are expressed as arbitrary units resulting from dividing the densitometric value obtained for each mRNA of interest by the corresponding cyclophilin value found in each sample.

Semiquantitative PCR Analysis of IA-1, TSG-6 and mGluR1A mRNA Expression in Monkey Hypothalamus

Five hundred nanograms of total RNA from each sample were reverse transcribed as indicated above. The PCR primers (online suppl. note 5, www.karger.com/doi/10.1159/000111815), chosen using Primer Express software (PR Applied Biosystems) were selected from monkey cDNA sequences (http://www.hgsc.bcm. tmc.edu/projects/rmacaque).

\section{Statistics}

Differences between two groups were analyzed using the Student $t$ test. When comparing several groups, the differences were analyzed by one-way ANOVA followed by the Student-NewmanKeuls multiple comparison test for unequal replications.

\section{Results}

\section{Identification of Genes Predominantly Expressed in an $\mathrm{HH}$ Associated with $\mathrm{CPP}$}

To identify genes sharing a similar expression profile in $\mathrm{HH}-1$ (the $\mathrm{HH}$ from patient 1 who had CPP and seizures) in comparison to $\mathrm{HH}-2$ to 4 (the HHs from patients 2-4 who had seizures, but not CPP at the time of surgery), we used a K-means clustering algorithm provided by J-Express 2.0 software (http://www.ii.uib.no/ $\sim$ bjarted/jexpress). A group of 10 genes whose expres- 
Table 3. Cellular and molecular functions of genes showing a 2 -fold increase or more in an $\mathrm{HH}$ associated with precocious puberty (HH-1) in comparison to HHs not accompanied by sexual precocity (HH-2 to 4)

\begin{tabular}{|c|c|c|c|c|}
\hline Gene identity & Cellular process & Molecular function & Tissue specificity & TRG \\
\hline Centromere protein $\mathrm{F}$ (mitosin) & Mitosis regulation & $\begin{array}{l}\text { Chromosome segregation: } \\
\text { microtubule binding protein }\end{array}$ & $\begin{array}{l}\text { Embryonic tissue, } \\
\text { malignant tissue }\end{array}$ & Yes \\
\hline Insulinoma-associated 1 (IA1) & $\begin{array}{l}\text { Transcriptional } \\
\text { regulation }\end{array}$ & $\begin{array}{l}\text { Transcription repressor of } \\
\text { NeuroD/beta2 }\end{array}$ & $\begin{array}{l}\text { Fetal brain, } \\
\text { fetal pancreas, } \\
\text { neuroendocrine tumors }\end{array}$ & Yes \\
\hline MEF2A transcription enhancer factor 2 & $\begin{array}{l}\text { Transcriptional } \\
\text { regulation }\end{array}$ & Activates transcription & $\begin{array}{l}\text { Muscle, } \\
\text { brain }\end{array}$ & Yes \\
\hline $\begin{array}{l}\text { Glutamate receptor metabotropic } 1 \alpha \\
\text { (mGluR1A) }\end{array}$ & $\begin{array}{l}\text { Cell-cell } \\
\text { communication }\end{array}$ & $\begin{array}{l}\text { Metabotropic glutamate } \\
\text { receptor }\end{array}$ & Brain & No \\
\hline Visinin-like 1 (VILIP-1) & $\begin{array}{l}\text { Cell-cell } \\
\text { communication }\end{array}$ & Calcium sensor protein & Brain, pancreas & Yes \\
\hline $\begin{array}{l}\text { Calcium channel, voltage-dependent, } \\
\beta_{2} \text {-subunit }\end{array}$ & $\begin{array}{l}\text { Cell-cell } \\
\text { communication }\end{array}$ & $\begin{array}{l}\text { Voltage-gated calcium } \\
\text { channel }\end{array}$ & Brain, heart, pancreas & No \\
\hline $\begin{array}{l}\text { Solute carrier family 4, sodium bicarbonate } \\
\text { cotransporter, member } 7 \text { (SLC4A7) }\end{array}$ & $\begin{array}{l}\text { Cell-cell } \\
\text { communication }\end{array}$ & $\begin{array}{l}\text { Coupled transport of sodium } \\
\text { and bicarbonate: maintains } \\
\text { intracellular } \mathrm{pH}\end{array}$ & Brain, testis, spleen & No \\
\hline Transmembrane protein 16C (C11ORF25) & $\begin{array}{l}\text { Cell-cell } \\
\text { communication }\end{array}$ & $\begin{array}{l}\text { Transporter for unidentified } \\
\text { substrate }\end{array}$ & Ear, brain & Yes \\
\hline $\mathrm{T}$ cell activation leucine repeat-rich protein & $\begin{array}{l}\text { Cell-cell } \\
\text { communication }\end{array}$ & Membrane protein & $\begin{array}{l}\text { Brain (adult and fetal), } \\
\text { kidney, ovary }\end{array}$ & No \\
\hline $\begin{array}{l}\text { Tumor necrosis alpha-stimulated gene } 6 \\
\text { (TSG-6) }\end{array}$ & $\begin{array}{l}\text { Cell adhesiveness, } \\
\text { cell-cell } \\
\text { communication }\end{array}$ & $\begin{array}{l}\text { Hyaluronic acid binding } \\
\text { protein }\end{array}$ & Brain, ovary & Yes \\
\hline
\end{tabular}

TRG = Tumor-related gene.

sion was consistently greater (2-fold or more) in $\mathrm{HH}-1$ than in $\mathrm{HH}-2$ to 4 was selected (table 2). The functions of the encoded proteins were determined using three different search tools: the Swiss-Prot database (www.expasy. ch), GOMiner (http://discover.nci.nih.gov/gominer/) and IHOP (www.ihop-net.org/UniPub/iHOP/). This analysis indicated that the genes overexpressed in $\mathrm{HH}-1$ encode proteins involved in three fundamental cellular processes: transcriptional regulation, cell-cell communication and cell adhesiveness (table 3). With the possible exception of CENP-F (mitosin), a cell cycle-regulated nuclear protein [9] found at very low levels in the normal brain (http://source.stanford.edu), but that is overexpressed in malignant tissues, including astrocytomas and meningiomas [10 and references therein], all other genes are highly expressed in the normal developing brain in either neurons, astrocytes or both (table 3).

Gene Expression Profiling of

Hypothalamic Hamartomas
Validation of the Array Results by

Semiquantitative PCR

Based on their perceived importance in the control of $\mathrm{HH}$ cell function, five of the genes overexpressed in $\mathrm{HH}-$ 1 were selected for PCR validation: $I A-1$ and MEF2A, two transcriptional regulators $[11,12]$; $m$ GluR1 and VILIP-1, two genes encoding proteins involved in cell-cell signalling $[13,14]$, and TSG-6, a gene encoding a multifunctional secreted protein that participates in cell-cell adhesion via binding to hyaluronan, a component of the extracellular matrix [15].

The increased abundance of IA-1 mRNA detected by PCR in HH-1 as compared to HH-2 and 4 (all from male patients) was essentially identical to that detected by DNA arrays (fig. 1a). HH-3, derived from a female patient who developed CPP shortly after $\mathrm{HH}$ resection, exhibited an abundance of $I A-1$ mRNA intermediate between $\mathrm{HH}$ - 


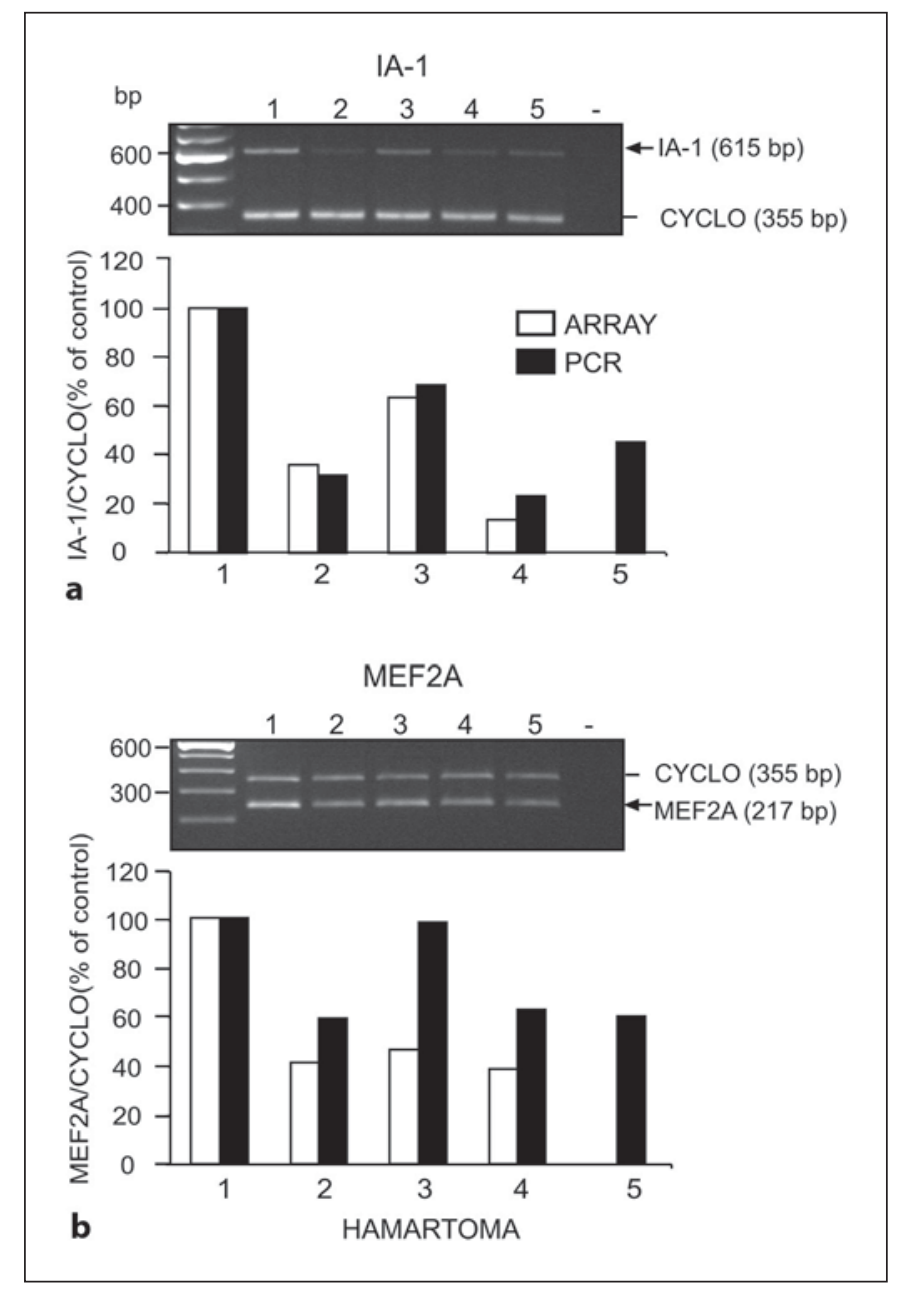

Fig. 1. Selective overexpression of the mRNAs encoding the transcriptional regulators IA-1 (a) and MEF2A (b) in an $\mathrm{HH}$ associated with CPP (HH-1) as compared with three HHs not accompanied by $\mathrm{CPP}$ (HH-2 to 4), and one $\mathrm{HH}(\mathrm{HH}-5)$ removed 9 years after the occurrence of CPP. White bars represent the relative levels of $I A-1$ and MEF2A mRNAs detected by cDNA arrays, using the mRNA levels found in $\mathrm{HH}-1$ as $100 \%$. Black bars represent relative expression levels detected by semiquantitative PCR, normalized to the cyclophilin mRNA content of each sample, and calculated using the mRNA levels in $\mathrm{HH}-1$ as $100 \%$. The gels depicting the PCR products used to calculate these densitometric values are shown on top of each bar graph. - = PCR, no RT control.

1, HH-2 and $\mathrm{HH}-4$, suggesting that $I A-1$ expression might have been already increasing at the time of surgery. IA-1 mRNA levels were not elevated in $\mathrm{HH}-5$, which was removed from a female patient 9 years after the diagnosis of CPP was made.

Consistent with the array results, $M E F 2 A$ mRNA content measured by PCR was higher in $\mathrm{HH}-1$ than in $\mathrm{HH}-2$ and 4 (fig. 1b). However, MEF2A mRNA levels in HH-1 were similar to those in $\mathrm{HH}-3$, a finding at variance with the array results that detected a 2 -fold increase in $M E F 2 A$ expression in $\mathrm{HH}-1$ as compared to $\mathrm{HH}-3$ (table 2). Like IA-1 mRNA, MEF2A expression was as low in $\mathrm{HH}-5$ as in HH-2 and 4.

The differences in mGluR1A and VILIP-1 mRNA abundance between $\mathrm{HH}-1$ versus $\mathrm{HH}-2,3$ and 4, assessed by semiquantitative PCR, were similar to those estimated by the arrays (fig. 2a, b). HH-5 had VILIP-1 mRNA levels as high as in HH-1, but $m$ GluR1A mRNA values as low as in $\mathrm{HH}-2,3$ and 4, suggesting that not all genes with increased expression in $\mathrm{HHs}$ associated with $\mathrm{CPP}$ remain permanently activated. As in the case of $I A-1$ and $m G l u R 1 A$, there was excellent agreement between the TSG-6 mRNA levels detected by PCR and the arrays (fig. 2c). TSG-6 mRNA prevalence in $\mathrm{HH}-5$ was as low as in $\mathrm{HH}-2,3$ and 4.

\section{Expression of GnRH, TGF $\alpha$, KiSS1 and GPR54 in $\mathrm{HHs}$}

Because earlier reports showed the presence of $\mathrm{GnRH}$ [16 and references therein] and TGF $\alpha$ [17] in HHs, expression of these genes was also examined. In addition, we sought to determine if KiSS1 and GPR54 are expressed in $\mathrm{HHs}$, because of recent findings indicating that activation of GPR54 receptors by kisspeptin, the processed protein product of the KiSS1 gene, is a critical transsynaptic input to $\mathrm{GnRH}$ neurons required for the initiation of $\mathrm{pu}-$ berty $[3,4]$.

As shown in figure $3 \mathrm{a}$ and $\mathrm{b}$, both $G n R H$ and $T G F \alpha$ mRNAs were detected in all five HHs examined, regardless of their association with CPP. GnRH mRNA levels were higher in $\mathrm{HH}-2$, despite the lack of association of this $\mathrm{HH}$ with precocious puberty, and TGF $\alpha$ mRNA abundance was highest in $\mathrm{HH}-3$, which resulted in CPP after resection of the tumor. KiSS1 mRNA was undetectable in all five HHs (fig. 3c), but GPR54 mRNA was expressed in some HHs (HH-1 to 3), and absent in others (HH-4 and 5) (fig. 3d). Thus activation of GPR54 receptors within HHs does not appear to be a primary mechanism by which HHs induce sexual precocity.

\section{Ontogeny of IA-1, mGluR1A and TSG-6 Expression in the Female Monkey Hypothalamus}

Because IA-1, mGluR1A and TSG-6 expression is consistently increased in $\mathrm{HH}-1$, we sought to determine if similar changes occur in the primate hypothalamus during the normal onset of puberty. Female rhesus monkeys were used, because the intrinsic neuroendocrine mecha- 


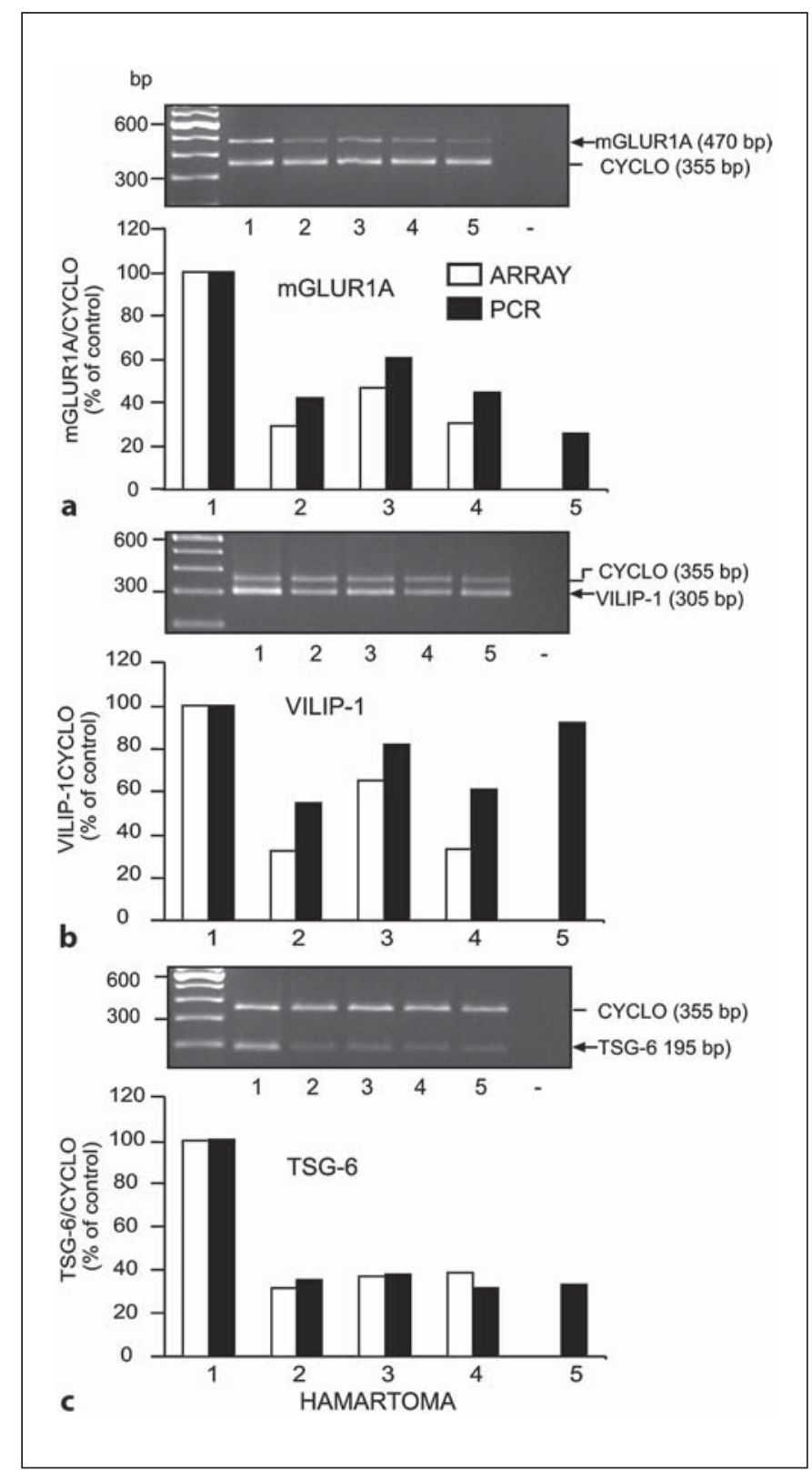

Fig. 2. Selective overexpression of the mRNAs encoding the cellcell communication molecules mGluR1A (a), VILIP-1 (b) and TSG-6 (c) in an HH associated with CPP (HH-1) as compared with three HHs not accompanied by $\mathrm{CPP}$ (HH-2 to 4), and one $\mathrm{HH}(\mathrm{HH}-5)$ removed 9 years after the occurrence of CPP. White bars represent the relative levels of $m$ GLUR1A, VILIP-1 and TSG6 mRNAs detected by cDNA arrays, using the mRNA levels found in $\mathrm{HH}-1$ as $100 \%$. Black bars represent relative expression levels detected by semiquantitative PCR, normalized to the cyclophilin mRNA content of each sample, and calculated using the mRNA levels in $\mathrm{HH}-1$ as $100 \%$. The gels depicting the PCR products used to calculate these densitometric values are shown on top of each bar graph. - = PCR, no RT control.

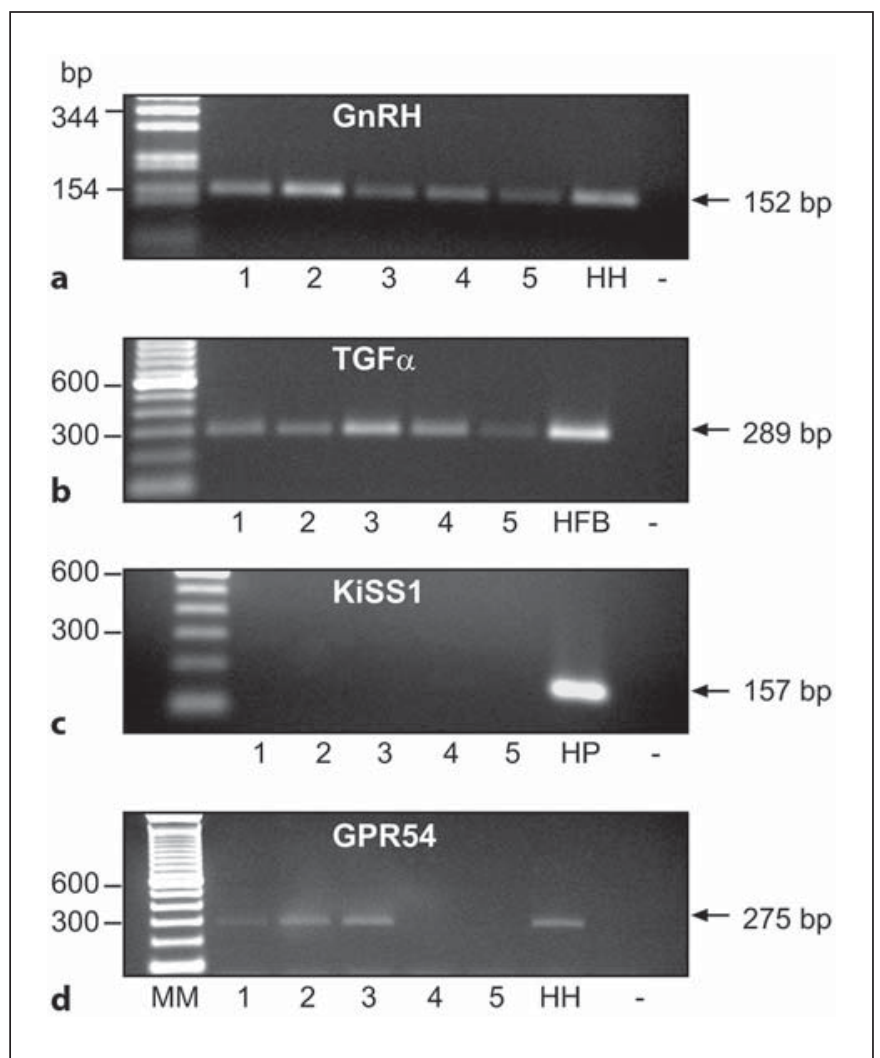

Fig. 3. The genes encoding GnRH (a), TGF $\alpha$ (b), KiSS1 (c) and GPR54 (d) are not selectively expressed in an $\mathrm{HH}$ associated with $\mathrm{CPP}(\mathrm{HH}-1)$ in comparison to three $\mathrm{HH}$ not accompanied by $\mathrm{CPP}$ (HH-2 to 4), and one $\mathrm{HH}(\mathrm{HH}-5)$ removed 9 years after the occurrence of CPP. Notice that while GnRH and TGF $\alpha$ are expressed in all HHs, KiSS1 is not expressed in any. In contrast GPR54 mRNA is found in three of the five HHs studied. Also notice that TGF $\alpha$ mRNA abundance is higher in $\mathrm{HH}-3$, which was resected from a patient who underwent CPP not before, but shortly after surgery. $\mathrm{MM}=$ Molecular marker; $-=\mathrm{PCR}$, no RT control; $\mathrm{HH}=$ human hypothalamus; $\mathrm{HFB}=$ human fetal brain; $\mathrm{HP}=$ human placenta.

nisms underlying the onset of puberty in this species are similar to those operating in humans [18]. The content of $m$ GluR1A mRNA increased $(\mathrm{p}<0.05)$ in the hypothalamus (fig. 4a), but not in the cerebral cortex (inset), at the initiation of puberty, remaining moderately elevated thereafter. Neither IA-1 nor TSG-6 mRNA abundance increased in the hypothalamus during postnatal development (fig. 4b, c).

\section{Identification of Genes with Decreased Expression in $\mathrm{HH}$ with $\mathrm{CPP}$}

Fifteen genes showed a 2-fold or greater decrease in expression in $\mathrm{HH}-1$ as compared with $\mathrm{HH}-2$ to 4 (online 


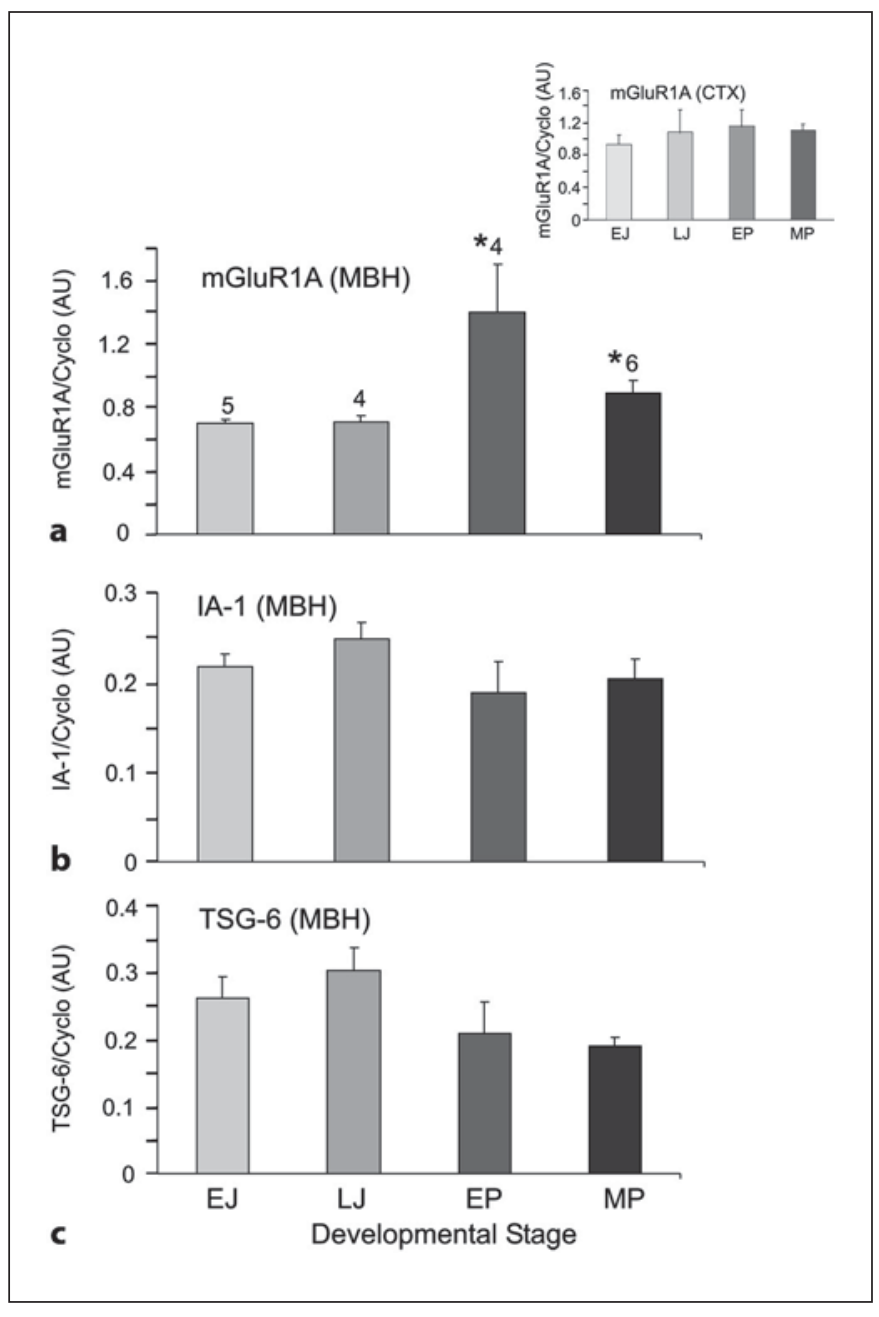

Fig. 4. Expression of $m G l u R 1 A$ (a), but not that of $I A-1$ (b) or TSG6 (c), increases in the medial basal hypothalamus (MBH) of female rhesus monkeys at the time of puberty, as assessed by semiquantitative PCR. Values are expressed as the ratio between each gene of interest and the levels of cyclophilin mRNA detected in each sample. The increase in hypothalamic mGluR1A mRNA content was not observed in the cerebral cortex (CTX, inset in a). ${ }^{*} \mathrm{p}<0.05$ vs. early juvenile group. EJ = Early juvenile (8.911.7 months of age); LJ = late juvenile (1.2-1.8 years of age); EP = early puberty ( $2-3$ years of age); $\mathrm{MP}=$ mid-puberty $(3-4$ years of age). Bars are mean and vertical bars represent SEM. Numbers on top of bars in a indicate the number of animals per group.

suppl.table 1, www.karger.com/doi/10.1159/000111815). The greatest decrease observed was in glutathione $\mathrm{S}$ transferase M5 (GSTM5) mRNA levels. GSTM5 is an enzyme that contributes to the detoxification of carcinogens, products of oxidative stress, and environmental toxins, by conjugation with glutathione [19]. Like the other 14 genes with decreased expression in $\mathrm{HH}-1$, the contribution of GSTM5 to HH-induced puberty is obscure.

\section{Discussion}

The present study demonstrates that expression of a discrete cohort of genes involved in transcriptional control, cell-cell communication and cell adhesiveness is increased in an $\mathrm{HH}$ associated with sexual precocity in comparison with $\mathrm{HHs}$ that do not elicit advanced sexual development. The common feature linking all cases (including HH-5, which was not analyzed by DNA arrays) is that all patients had seizures, and all had been unsuccessfully treated with antiepileptic drugs prior to surgery. However, because HHs are only resected when they give rise to intractable seizures, the number of $\mathrm{HHs}$ available for analysis was necessarily small and variable with regard to age at surgery, gender of the patients, and pubertal history.

Despite these differences, the selective increase in gene expression observed in $\mathrm{HH}-1$ was remarkably consistent with the neuroendocrine clinical features of each patient. Thus HH-2 and 4, derived from patients in whom sexual precocity never occurred, exhibited essentially identical differences in gene expression when compared to HH-1. The differences between $\mathrm{HH}-1$ and $\mathrm{HH}-3$ were uniformly less accentuated, and they were more variable in the case of the few HH-5 genes examined. It is, therefore, possible that the initiation of puberty observed in patient 3 after surgery may have been related to activation of the same genes whose expression is increased in $\mathrm{HH}-1$. The increased prevalence of TGF $\alpha$ mRNA found in this $\mathrm{HH}$ is consistent with this possibility. Judging from the limited information gathered from $\mathrm{HH}-5$, it would also appear that gene activation is not a permanent feature of $\mathrm{HH}$ neuropathology. The fact that sexual precocity was arrested in patients 1 and 5 by long-term GnRH antagonist treatment is also an important factor that needs to be taken into account when interpreting the results, because the GnRH treatment itself may have caused some of the changes in gene expression we detected.

The present results do not identify gene defects that may be responsible for the development of $\mathrm{HHs}$, but suggest that $\mathrm{HHs}$ associated with $\mathrm{CPP}$ have a gene expression profile distinct from that of $\mathrm{HHs}$ not eliciting premature sexual development. They also suggest that genes showing increased expression in the $\mathrm{HH}$ associated with $\mathrm{CPP}$ may be more useful for an understanding of this condi- 
tion than genes with a decreased expression. Examination of additional HHs associated with sexual precocity is necessary to verify the validity of these concepts.

We recently used DNA microarrays to query the hypothalamus of female rhesus monkeys during pubertal development (Roth et al., unpubl. data), and quantitative proteomics to identify hypothalamic proteins that might be down- or upregulated in a mouse model of delayed puberty [20]. The results of these studies showed that expression of certain genes previously described as being involved in 'tumor suppression' - but that otherwise play a role in maintaining normal cell differentiation processes - increases in the hypothalamus at the time of monkey puberty (Roth et al., unpubl. data) or decreases in mice with delayed puberty [20]. A prominent example of a tumor suppressor gene now found to play a critical role in the initiation of puberty is KiSS1 [3, 4]. Before its function in the control of puberty was discovered, KiSS1 was known as a suppressor of tumor metastases [21].

Of the 10 genes showing increased expression in $\mathrm{HH}-$ 1 , six had been earlier proposed to have roles in tumor suppression. One of them is CENP-F [10]. Two others, IA1 (insulinoma-associated-1, also known as INSM1) and $M E F 2 A$, are transcription factors. IA-1 is a zinc finger transcriptional repressor involved in neuronal differentiation with expression restricted to the embryonic nervous system and neuroendocrine tumors [11 and references therein]. MEF2A, is a transcription factor also required for neuronal differentiation and survival [12], in addition to dendritic arborization and dendritic spine formation [22]. Two additional genes related to tumor formation play a physiological role in cell-cell communication. One of them, VILIP-1 (visinin-like protein-1) is a member of the family of neuronal calcium sensor proteins [14]; loss of VILIP-1 expression is associated with accelerated tumor cell invasiveness [23]. C11ORF25 encodes an eight-transmembrane protein with similarity to three other genes located on chromosomes 11 and 12; like other members of the family, C11ORF25 is amplified in malignant tumors [24]. C11ORF25 is predicted to be involved in the intracellular transport of yet to be identified molecules. Finally, TSG-6 (tumor necrosis factor-stimulated gene 6) was also highly expressed in HH-1. TSG-6 is a multifunctional protein secreted in response to TNF $\alpha$ stimulation and elevated cAMP levels that binds to hyaluronan, a component of the extracellular matrix [15]. As a downstream component of p53-mediated cell cycle arrest [25], TSG-6 is a potential tumor suppressor gene. It thus appears that in both normal puberty and HHs there is an activation of genes that, having diverse cellular func- tions, share the common feature of having been earlier identified as involved in tumor suppression.

An additional gene encoding a protein involved in cell-cell communication and found to be upregulated in $\mathrm{HH}-1$ is much less well-characterized. This gene, $\mathrm{T}$ cell activation leucine-rich repeat containing 8 (LRRC8) is a member of a highly conserved family of leucine-rich repeat proteins; LRRC8 may function as a receptor for an unknown ligand [26].

Two genes encoding proteins involved in transmembrane ion mobilization are also overexpressed in $\mathrm{HH}-1$ : a splice variant of the L-type high voltage-activated $\mathrm{Ca}_{\mathrm{v}} 1.2$ channel $\beta$-subunit [27], and the sodium bicarbonate cotransporter NBC3 (SLC4A7) [28]. The $\beta$-subunits of L$\mathrm{Ca}^{2+}$ channels are critical modulators of the channel's gating activity, and are required for the correct targeting of the $\mathrm{Ca}_{\mathrm{v}} 1.2$ complex to the cell membrane [29]. Sodiumcoupled bicarbonate transporters are essential for the homeostatic maintenance of intracellular $\mathrm{pH}$ [28]. Mice lacking $N B C 3$ develop blindness and hearing loss due to degeneration of the corresponding sensory receptors, a condition similar to Usher syndrome [30].

Among the genes showing increased expression in HH-1, IA-1 and VILIP-1 deserve special mention because of their reported role in pancreatic $\beta$-cell/intestinal endocrine cell differentiation [31] and insulin secretion [32], respectively. Like in the pancreas, IA-1 might function in HHs to promote the differentiation of neurosecretory cells. IA-1 is highly expressed in the fetal brain, pancreas, and neuroendocrine tumors, but is absent in adult tissues $[11,33]$. VILIP-1, a neuronal calcium sensor protein [14], is also expressed in pancreatic $\beta$-cells where it modulates insulin secretion instead of cell differentiation [32]. VILIP-1 also appears to mediate metabotropic receptor-induced synaptic plasticity [34]. Conceivably, coupling of mGluR1 to VILIP-1 may set in motion cAMPand cGMP-dependent pathways [14] that enhance the secretion of substances, such as $\mathrm{PGE}_{2}$, able to stimulate GnRH release. These considerations suggest that the defining feature distinguishing $\mathrm{HHs}$ able to induce $\mathrm{CPP}$ from $\mathrm{HHs}$ not associated with sexual precocity is the presence of active neuroendocrine cells in $\mathrm{HH}$ causing CPP. Of interest in this context is a recently described case of precocious puberty in a 2-year-old girl caused by a pancreatic neuroectodermal tumor [35].

Previous studies showed that $\mathrm{HHs}$ are composed of mature neuronal and glial elements [36, 37]. The functions of the 10 genes found to be overexpressed in $\mathrm{HH}-1$ provide molecular support to this concept, because all of them, with the possible exception of CENP-F, are involved 
in the regulation of differentiated neural cell functions $[12,13,22,27,28,38]$. Noteworthy, the overexpression of TSG-6, a gene encoding a secreted protein that binds to the extracellular matrix component glycosaminoglycan hyaluronan [15], may reflect the presence of growth factor-producing glia in HH-1, because TSG- 6 synthesis is strongly upregulated by glial growth factors, such as bFGF, TGF $\alpha$, TNF $\alpha$ and TGF $\beta$ [39].

Also of interest is the finding that all five $\mathrm{HHs}$ contained GnRH and TGF $\alpha$ mRNA, but only HH-1 and HH5 were associated with precocious puberty before surgery, suggesting that $\mathrm{GnRH}$ neurons and TGF $\alpha$-producing glia in $\mathrm{HHs}$ require a set of additional genes to become engaged in the cascade of events that allow $\mathrm{HH}$ s to induce sexual precocity. Interestingly, $\mathrm{HH}-3$ had not only the gene expression profile most similar to $\mathrm{HH}-1$, but also exhibited elevated TGF $\alpha$ mRNA levels, suggesting that this combination may have contributed to the prompt, and surprising, initiation of puberty seen in this patient after removal of the $\mathrm{HH}$. The additional genes required for $\mathrm{HHs}$ to induce precocious puberty do not appear to include the KiSS1/GPR54 signaling complex because none of the HHs expressed KiSS1 mRNA, and the presence of GPR54 receptors was unrelated to the ability of the $\mathrm{HH}$ to elicit sexual precocity.

The onset of normal female puberty in nonhuman primates was not accompanied by increased hypothalamic expression of $I A-1$ or TSG-6, but it did show an increased abundance of $m G l u R 1 A$ mRNA. These findings suggest that either the increases in IA-1 and TSG-6 mRNA content observed in $\mathrm{HH}-1$ do not occur during normal puberty, or that they reflect the presence in the $\mathrm{HH}$ of a subset of differentiated neurons and glial cells that represent only a small fraction of cells in the whole hypothalamus. Such a small population of cells would be difficult to detect by PCR analysis of the whole medial basal hypothalamus. It is also possible that the alterations in gene expression observed in $\mathrm{HH}-1$ are gender-dependent, and that, because of this, are not readily detectable in female monkeys undergoing normal puberty. Further studies are necessary not only to resolve these issues, but also to determine if expression in an in vitro context of key genes overexpressed in $\mathrm{HH}-1$ results in the production of $\mathrm{GnRH}$ secretagogues able to accelerate the onset of puberty.

\section{Acknowledgements}

This work was supported by grants from the National Institutes of Health HD25123, U54 HD18185 through cooperative agreement as part of the Specialized Cooperative Centers Program in Reproduction and Infertility Research, National Institute of Child Health and Human Development/NIH, and RR00163 for the operation of the Oregon National Primate Research Center.

ASP was a postdoctoral researcher supported by the Fonds National de la Recherche Scientifique in Belgium. VM was a fellow supported by the Belgian American Educational Foundation, Francqui and Coleen Fellowship.

\section{References}

1 Ojeda SR, Terasawa E: Neuroendocrine regulation of puberty; in Pfaff D, Arnold A, Etgen A, Fahrbach S, Moss R, Rubin R (eds): Hormones, Brain and Behavior. New York, Elsevier, 2002, vol 4, pp 589-659.

2 Dungan HM, Clifton DK, Steiner RA: Minireview: kisspeptin neurons as central processors in the regulation of gonadotropin-releasing hormone secretion. Endocrinology 2006;147:1154-1158.

-3 de Roux N, Genin E, Carel J-C, Matsuda F, Chaussain J-L, Milgrom E: Hypogonadotropic hypogonadism due to loss of function of the KiSS1-derived peptide receptor GPR54. Proc Natl Acad Sci USA 2003;100: 10972-10976.

-4 Seminara SB, Messager S, Chatzidaki EE, Thresher RR, Acierno JS Jr, Shagoury JK, BoAbbas Y, Kuohung W, Schwinof KM, Hendrick AG, Zahn D, Dixon J, Kaiser UB, Slaugenhaupt SA, Gusella JF, O'Rahilly S, Carlton MB, Crowley WF Jr, Aparicio SA, Colledge $\mathrm{WH}$ : The GPR54 gene as a regulator of puberty. N Engl J Med 2003;349:1614-1627.
5 Jung H, Parent AS, Ojeda SR: Hypothalamic hamartoma: a paradigm/model for studying the onset of puberty; in Delemarre-van de Waal HA (ed): Abnormalities in Puberty. Scientific and Clinical Advances. Endocr Dev. Basel, Karger, 2005, pp 81-93.

-6 Zuniga OF, Tanner SM, Wild WO, Mosier HD Jr: Hamartoma of CNS associated with precocious puberty. Am J Dis Child 1983; 137:127-133.

7 Dammann O, Commentz JC, Valdueza JM, Christante L, Bentele KH: Gelastic epilepsy and precocious puberty in hamartoma of the hypothalamus. Klin Pädiatr 1991;203:439447.

8 Watanabe G, Terasawa E: In vivo release of luteinizing hormone releasing hormone increases with puberty in the female rhesus monkey. Endocrinology 1989;125:92-99.
9 Hussein D, Taylor SS: Farnesylation of Cenp$\mathrm{F}$ is required for $\mathrm{G} 2 / \mathrm{M}$ progression and degradation after mitosis. J Cell Sci 2002;115: 3403-3414.

10 Korkolopoulou P, Patsouris E, Konstantinidou AE, Christodoulou P, Thomas-Tsagli E, Kouzelis K, Angelidakis D, Rologis D, Davaris P: Mitosin and DNA topoisomerase IIalpha: two novel proliferation markers in the prognostication of diffuse astrocytoma patient survival. Appl Immunohistochem Mol Morphol 2001;9:207-214.

11 Breslin MB, Zhu M, Lan MS: NeuroD1/E47 regulates the E-box element of a novel zinc finger transcription factor, IA-1, in developing nervous system. J Biol Chem 2003;278: 38991-38997.

12 Heidenreich KA, Linseman DA: Myocyte enhancer factor-2 transcription factors in neuronal differentiation and survival. Mol Neurobiol 2004;29:155-166. 
13 Bortolotto ZA, Fitzjohn SM, Collingridge GL: Roles of metabotropic glutamate receptors in LTP and LTD in the hippocampus. Curr Opin Neurobiol 1999;9:299-304.

-14 Braunewell K-H, Gundelfinger ED: Intracellular neuronal calcium sensor proteins: a family of EF-hand calcium-binding proteins in search of a function. Cell Tissue Res 1999; 295:1-12.

15 Wisniewski HG, Vilcek J: Cytokine-induced gene expression at the crossroads of innate immunity, inflammation and fertility: TSG6 and PTX3/TSG-14. Cytokine Growth Factor Rev 2004;15:129-146.

16 Culler FL, James HE, Simon ML, Jones KL: Identification of gonadotropin-releasing hormone in neurons of a hypothalamic hamartoma in a boy with precocious puberty. Neurosurgery 1985;17:408-412.

17 Jung H, Carmel P, Schwartz MS, Witkin JW, Bentele KHP, Westphal M, Piatt JH, Costa ME, Cornea A, Ma YJ, Ojeda SR: Some hypothalamic hamartomas contain transforming growth factor alpha, a puberty-inducing growth factor, but not luteinizing hormonereleasing hormone neurons. J Clin Endocrinol Metab 1999;84:4695-4701.

18 Plant TM, Witchel SF: Puberty in nonhuman primates and humans; in Neill JD (ed): The Physiology of Reproduction, ed 3. San Diego, Academic Press/Elsevier, 2006, pp 21772230.

19 Rowe JD, Nieves E, Listowsky I: Subunit diversity and tissue distribution of human glutathione S-transferases: interpretations based on electrospray ionization-MS and peptide sequence-specific antisera. Biochem J 1997;325:481-486.

20 Mungenast AE, Parent A, Chen SS, Goodlett D, Aebersold R, Corfas G, Ojeda SR: The synaptic adhesion molecule SynCAM is associated with ERBB4 dysregulation in the hypothalamus of mice with a delayed onset of puberty. Program No 281 20, 2003 Abstract Viewer. Washington, Society for Neuroscience, 2003 Online.

-21 Ohtaki T, Shintani Y, Honda S, Matsumoto H, Hori A, Kanehashi K, Terao Y, Kumano S, Takatsu Y, Masuda Y, Ishibashi Y, Watanabe T, Asada M, Yamada T, Suenaga M, Kitada C, Usuki S, Kurokawa T, Onda H, Nishimura O, Fujino M: Metastasis suppressor gene KiSS-1 encodes peptide ligand of a G-protein-coupled receptor. Nature 2001;411:613-617.
22 Flavell SW, Cowan CW, Kim TK, Greer PL, Lin Y, Paradis S, Griffith EC, Hu LS, Chen C, Greenberg ME: Activity-dependent regulation of MEF2 transcription factors suppresses excitatory synapse number. Science 2006; 311:1008-1012.

23 Mahloogi H, Gonzáles-Guerrico AM, Lopez De Cicco R, Bassi ED, Goodrow T, Braunewell K-H, Klein-Szanto JP: Overexpression of the calcium sensor visinin-like protein-1 leads to a cAMP-mediated decrease of in vivo and in vitro growth and invasiveness of squamous cell carcinoma cells. Cancer Res 2003; 63:4997-5004

24 Katoh M, Katoh M: FLJ10261 gene, located within the CCND1-EMS1 locus on human chromosome 11q13, encodes the eight-transmembrane protein homologous to C12orf3, C11orf25 and FLJ34272 gene products. Int J Oncol 2003;22:1375-1381.

25 Seidita G, Polizzi D, Costanzo G, Costa S, D Leonardo A: Differential gene expression in p53-mediated G1 arrest of human fibroblasts after $\gamma$-irradiation or N-phosphoacetyl-Laspartate treatment. Carcinogenesis 2000; 21:2203-2210.

-26 Kubota K, Kim JY, Sawada A, Tokimasa S, Fujisaki H, Matsuda-Hashii Y, Ozono K, Hara J: LRRC8 involved in B cell development belongs to a novel family of leucinerich repeat proteins. FEBS Lett 2004;564: 147-152.

27 Harry JB, Kobrinsky E, Abernethy DR, Soldatov NM: New short splice variants of the human cardiac Cavbeta2 subunit: redefining the major functional motifs implemented in modulation of the Cav1.2 channel. J Biol Chem 2004;279:46367-46372.

28 Pushkin A, Abuladze N, Lee I, Newman D, Hwang J, Kurtz I: Cloning, tissue distribution, genomic organization, and functional characterization of NBC3, a new member of the sodium bicarbonate cotransporter family. J Biol Chem 1999;274:16569-16575.

29 Takahashi SX, Mittman S, Colecraft HM: Distinctive modulatory effects of five human auxiliary beta 2 subunit splice variants on Ltype calcium channel gating. Biophys J 2003 84:3007-3021.
30 Bok D, Galbraith G, Lopez I, Woodruff M, Nusinowitz S, BeltrandelRio H, Huang W, Zhao S, Geske R, Montgomery C, Van Sligtenhorst I, Friddle C, Platt K, Sparks MJ, Pushkin A, Abuladze N, Ishiyama A, Dukkipati R, Liu W, Kurtz I: Blindness and auditory impairment caused by loss of the sodium bicarbonate cotransporter NBC3. Nat Genet 2003;34:313-319.

-31 Gierl MS, Karoulias N, Wende H, Strehle M, Birchmeier C: The zinc-finger factor Insm1 (IA-1) is essential for the development of pancreatic beta cells and intestinal endocrine cells. Genes Dev 2006;20:2465-2478.

32 Dai FF, Zhang Y, Kang Y, Wang Q, Gaisano $\mathrm{HY}$, Braunewell KH, Chan CB, Wheeler MB: The neuronal $\mathrm{Ca}^{2+}$ sensor protein visininlike protein-1 is expressed in pancreatic islets and regulates insulin secretion. J Biol Chem 2006;281:21942-21953.

-33 Goto Y, De Silva MG, Toscani A, Prabhakar BS, Notkins AL, Lan MS: A novel human insulinoma-associated cDNA, IA-1, encodes a protein with 'zinc-finger' DNA-binding motifs. J Biol Chem 1992;267:15252-15257.

-34 Braunewell KH, Brackmann M, ManahanVaughan D: Group I mGlu receptors regulate the expression of the neuronal calcium sensor protein VILIP-1 in vitro and in vivo: implications for $\mathrm{mGlu}$ receptor-dependent hippocampal plasticity? Neuropharmacology 2003;44:707-715.

35 Schutte WP, Knight PJ: Precocious puberty because of a pancreatic neuroectodermal tumor. J Pediatr Surg 2006;41:1916-1918.

36 Freeman JL: The anatomy and embryology of the hypothalamus in relation to hypothalamic hamartomas. Epileptic Disord 2003;5: 177-186.

- 37 Jung H, Probst EN, Hauffa BP, Partsch C-J, Dammann O: Association of morphological characteristics with precocious puberty and/ or gelastic seizures in hypothalamic hamartoma. J Clin Endocrinol Metab 2003;88: 4590-4595.

>38 Bernstein HG, Baumann B, Danos P, Diekmann S, Bogerts B, Gundelfinger ED, Braunewell KH: Regional and cellular distribution of neural visinin-like protein immunoreactivities (VILIP-1 and VILIP-3) in human brain. J Neurocytol 1999;28:655-662.

-39 Milner CM, Day AJ: TSG-6: a multifunctional protein associated with inflammation. J Cell Sci 2003;116:1863-1873. 